\title{
Effects of environmental factors on the growth response of above- and below-ground parts of Mankyua chejuense, endangered endemic plant to Jeju province, in Korea
}

\author{
Hae-Ran Kim ${ }^{1}$, Jeong-Hoon Shin ${ }^{2}$, Heon-Mo Jeong ${ }^{3}$ and Young-Han You, \\ ${ }^{1}$ Warm-Temperate and Subtropical Forest Research Center, KFRI, Jeju 697-050, Korea \\ ${ }^{2}$ Department of Biology, Kongju National University, Kongju 314-701, Korea \\ ${ }^{3}$ Ecological Adaptation Research Team, Institute of National Ecology, Seocheon 325-813, Korea
}

\begin{abstract}
Mankyua chejuense is a native endangered plant distributed only in Gotzawal, a forested wetland, in Jeju Province, Korea. In order to determine the optimal environmental conditions for the growth and development of M. chejuense, we investigated the above- and below-ground growth responses and survival rate to various soil texture (sand and clay), water regimes (flooding and non-flooding), and $\mathrm{CO}_{2}+\mathrm{T}$ (ambient and elevated) conditions. All of the treatments had significant effects on aboveground growth parameters, while only the water regime and $\mathrm{CO}_{2}+\mathrm{T}$ treatments influenced belowground growth. The survival rate of $M$. chejuense was about twice higher under the sand, non-flooding and elevated $\mathrm{CO}_{2}+\mathrm{T}$ conditions than clay, flooding and ambient $\mathrm{CO}_{2}+\mathrm{T}$ conditions. These results indicate that $M$. chejuense grows in well-drained sandy soil conditions and elevated $\mathrm{CO}_{2}$ concentration and temperature situations. Thus, there is a need to maintain $M$. chejuense under constant non-flooding soil conditions by implementing appropriate soil drainage strategies.
\end{abstract}

Key words : fern, flooding, global warming, rhizome, soil texture, sporophyll

\section{INTRODUCTION}

Mankyua chejuense is an endangered endemic fern to Jeju Island in Korea (Ministry of Environment of Korea 2009). The Korean peninsula has seven endemic genera; Pentactina, Hanabusaya, Echinosophora, Megaleranthis, Abeliophyllum, Coreanomecon, and Mankyua (Kim 2006). Mankyua chejuense is a monotypic fern genus belonging to the family Ophioglossaceae (Sun et al. 2001).

The distribution of $M$. chejuense is restricted to Gotzawal, a unique forested inland wetland, in the northeast region of Jeju Island that is fed by underground water in the rocky volcanic area (Hyeon et al. 2011, Lee et al. 2012). Mankyua chejuense is only found in small vernal pools with a variety of shapes and a small amount of soil and nutrients. The fern grows within the lowland deciduous forest community at above $0^{\circ} \mathrm{C}$ during all the seasons (Lee et al. 2012).

Mankyua chejuensis currently has a small population size of 23 meta populations and is subject to minor changes in environmental conditions such as plant succession to the evergreen seral stage, litter accumulation and water drainage due to its small size (height $<5 \mathrm{~cm}$ ), as well as its ecological and reproductive characteristics (Shin 2012).

Rare and endangered species with limited climatic ranges or restricted habitat requirements are generally less tolerant to environmental stresses and have lower http://dx.doi.org/10.5141/ecoenv.2014.008

(1) \$ This is an Open Access article distributed under the terms of the Creative Commons Attribution Non-Commercial Licens (http://creativecommons.org/licenses/by-nc/3.0/) which permits unrestricted non-commercial use, distribution, and reproduction in any medium, provided the original work is properly cited.
Received 19 October 2013, Accepted 18 March 2014

*Corresponding Author

E-mail: youeco21@kongju.ac.kr

Tel: +82-41-850-8508 
phenotypic plasticity during acclimation to a broader range of environmental conditions than widely-distributed species (Sakai et al. 2001, Parmesan and Yohe 2003, Baruch and Jackson 2005). Thus, to understand any plant, it is important to obtain basic ecological information regarding the population response to diverse environmental factors such as soil, water and temperature by conducting detailed field- and laboratory-based ecological and physiological measurements (Jeffries 2006).

Recently, Kimball et al. (1993) demonstrated that elevated $\mathrm{CO}_{2}$ concentrations and increased temperatures have had profound effects on plant life history. Native species specific to local regions may be negatively affected than widespread species under global warming (Song et al. 2009), and thus at greater risk of extinction. However, there has been attempt to elucidate the growth response or belowground dynamics of this plant to environmental gradient conditions, despite the fact that this information is essential to plant population conservation and habitat management (You and Kim 2010).

In the present study, we measured the survival rate, and aboveground- and belowground growth under various soil textures, water regimes, $\mathrm{CO}_{2}$ concentration and temperature to verify the growth response of above- and below-ground parts of $M$. chejuense to different environmental conditions.

\section{MATERIALS AND METHODS}

\section{Environmental treatment}

The soil texture treatments were sand (1-2 mm particle size), or clay (particle size $<0.2 \mathrm{~mm}$ ) which consisted of vermiculite. The water regimes were flooding (maintenance of water at $1-2 \mathrm{~cm}$ above the root), and nonflooding, which were achieved by pouring water into the growth pots and releasing it through holes in the bottom.

Global warming treatment was ambient $\mathrm{CO}_{2}$ and ambient temperature (ACAT) and elevated $\mathrm{CO}_{2}$ and elevated temperature (ECET). In the ACAT, the air is maintained at the ambient $\mathrm{CO}_{2}$ concentration and temperature of the immediately surrounding air, which averages about 370$380 \mathrm{ppm}$ on a 24-hours basis. The ECET was maintained by inputting a small quantity of pure $\mathrm{CO}_{2}$ through two perforated plastic hoses so as to maintain the $\mathrm{CO}_{2}$ concentration at approximately $742.30 \pm 16.92 \mathrm{ppm}$, which is twice that of the ambient $(360.38 \pm 9.19 \mathrm{ppm})$ concentration. $\mathrm{CO}_{2}$ concentration was monitored by a TEL-7001 $\mathrm{CO}_{2}$ sensor (Onset Computer, Bourne, MA, USA) at 30- min intervals, and data was stored on HOBO U12 datalogger (Onset Computer, Bourne, MA, USA) to evaluate the stability of the $\mathrm{CO}_{2}$ concentration in the treatment. According to IPCC scenario (2007), the atmospheric $\mathrm{CO}_{2}$ concentration is predicted to be double within the next 100 years.

The mean temperature in the treatment was about $2.5^{\circ} \mathrm{C}$ higher than the control. The air temperature was measured using a TR-71U thermo recorder (T\&D Co., Matsumoto, Japan) at the same height in the control and treatment greenhouses during the study period. This study was conducted in glass greenhouse of $12 \mathrm{~m} \times 7.8 \mathrm{~m}$ $\times 5 \mathrm{~m}$ (length $\times$ width $\times$ height). The floor surface area of each control and treatment is $46.8 \mathrm{~m}^{2}$.

Four individual ramets of $M$. chejuensis collected from natural habitat, Jeju Island, were transplanted in each plastic pot $(30 \mathrm{~cm} \times 20 \mathrm{~cm} \times 10 \mathrm{~cm})$ in November 2009 . Four pots were assigned into soil texture, water states and global warming treatments condition, respectively. Pots were given additional organic fertilizer (Monsanto Korea Inc., Seoul, Korea) which contains an ammonium nitrogen content below $170 \mathrm{mg} / \mathrm{L}$ and nitrate nitrogen at a concentration of 150-330 mg/L two times, at each spring for two experimental years.

\section{Growth parameters}

At the end of the study in November 2011, we counted the number of shoot, leaves, sporophyll and measured the length of shoot and sporophyll. Belowground growth of $M$. chejuense was calculated as the increment of number of rhizome, total rhizome length, rhizome diameter and total rhizome area from initial measured value in 2009 to the last measured value in 2011. Total length and area of rhizome were measured using an image analyser with the Root Measurement System software, ver. 1.11 (Skye Instruments, Llandrindod Wells, UK). Survival rate was determined from the changes in shoot number during two years.

\section{Statistical analyses}

The effects of soil texture, water and elevated $\mathrm{CO}_{2}+\mathrm{T}$ on the aboveground and belowground growth parameters of $M$. chejuense measured in this study were confirmed via one-way ANOVA and then the statistical differences between environmental gradients were evaluated via Fisher's least significant difference test as post-hocs, with significance at $P=0.05$.

The multivariate analysis of variance (MANOVA) is a 
complex statistic similar to ANOVA but with multiple dependent variables analyzed together. That is, the MANOVA is a multivariate extension of ANOVA (Zar 2009). MANOVA was used to analyze the effects of soil texture, water and elevated $\mathrm{CO}_{2}+\mathrm{T}$ and their interaction on aboveand below-ground growth of $M$. chejuense. All statistical analyses were performed at 0.05 levels with STATISTICA 8 software (Statsoft, Inc. Tulsa, OK, USA).

\section{RESULTS AND DISCUSSION}

Plant growth responds to multiple environmental factors, light, water, temperature and soil properties, also two or more resources simultaneously limit plant development (Chapin et al. 1987). Unfortunately for most endangered species, little information is available on their ecological requirements. Thus, it is necessary to determine optimal environmental conditions of species for the conservation of rare and endangered plants (Smith et al. 1993). According to Lee et al. (2012), the habitats of $M$. chejuense have a high ratio of rock exposure, shallow and wet soil layer, but experimental studies on the optimal environmental conditions for growth is unknown. Thus, we determined the effects of environmental factors on above- and below-ground growth and development of $M$. chejuense.

As a result, the pooled data of the $M$. chejuense showed significant soil texture, water and $\mathrm{CO}_{2}+\mathrm{T}$ effects on all aboveground growth parameters, and the significant interaction effects of those were observed except for the length of sporophyll (Table 1).

The average aboveground growth response for M. chejuense grown under the three environmental treatments is shown in Fig. 1. Number and length of shoot of the $M$. chejuense were higher at sand and ECET gradient that at clay and ACAT gradient, but those of $M$. chejuense were not significantly affected by water regimes (Fig. la and 1b). The number of sporophyll was higher at elevated $\mathrm{CO}_{2}$ concentration and temperature than ambient ones, while those were not significantly affected by soil texture and water regimes (Fig. 1c), while sporophyll length of $M$. chejuense grown under the sand and ECET treatments were longer than those grown under the clay and ACAT treatments (Fig. 1d).

Growth and potential reproduction in pteridophyte are reflected in the number of leaves that are produced within a given time period (Sharpe and Mehltreter 2010). In the present study, there were significant water and $\mathrm{CO}_{2}+\mathrm{T}$ effects on number of leaves (Fig. 1e). The number of leaves of M. chejuense was higher at non-flooding (NF) than flooding (F) and M. chejuense grown at ECET had a lot more leaves than plants grown at ACAT.

Many pteridophytes supplement their sexual cycles with various forms of vegetative reproduction (Yatskievych 2003). The branching of the rhizome and formation of adventitious buds on rhizomes is ferns of Ophioglossaceae have been reported (McMaster 1996). According to Kim (2004), M. chejuense propagates vegetatively by occurrence of branches arising as adventitious buds on older portions of the rhizome only when the rhizome has attained a certain length. Thus, the rhizome development of $M$. chejuense may be directly related to reproductive success.

Unlike aboveground growth responses to three environmental factors, the development and growth of aboveground of $M$. chejuense were significantly affected by water and $\mathrm{CO}_{2}+\mathrm{T}$ treatments expect for soil texture (Table 2).

The growth increment of the number and total area of rhizome showed similar trends (Fig. 2a and 2d) between 2009 and 2011. The mean number and total area of rhi-

Table 1. Effects of environmental factors and their interactions on aboveground growth of Mankyua chejuense

\begin{tabular}{|c|c|c|c|c|c|c|c|c|c|c|}
\hline \multirow{2}{*}{ Factors } & \multicolumn{2}{|c|}{ No. of shoot } & \multicolumn{2}{|c|}{ No. of sporophyll } & \multicolumn{2}{|c|}{ No. of leaves } & \multicolumn{2}{|c|}{ Shoot length $(\mathrm{cm})$} & \multicolumn{2}{|c|}{ Sporophyll length $(\mathrm{cm})$} \\
\hline & $F$ & $P$ & $F$ & $P$ & $F$ & $P$ & $F$ & $P$ & $F$ & $P$ \\
\hline Soil texture $(S)$ & 11.943 & $<0.002$ & 6.141 & $<0.020$ & 6.860 & $<0.028$ & 15.839 & $<0.000$ & 16.375 & $<0.000$ \\
\hline Water $(W)$ & 9.561 & $<0.005$ & 6.862 & $<0.014$ & 11.967 & $<0.028$ & 10.644 & $<0.003$ & 8.313 & $<0.008$ \\
\hline $\mathrm{CO}_{2}+\mathrm{T}(C)$ & 21.795 & $<0.000$ & 22.502 & $<0.000$ & 14.859 & $<0.000$ & 12.370 & $<0.002$ & 15.433 & $<0.000$ \\
\hline$S \times W$ & 0.298 & ns & 0.847 & ns & 0.002 & ns & 0.283 & ns & 0.892 & ns \\
\hline$S \times C$ & 0.180 & ns & 0.125 & ns & 0.022 & ns & 1.448 & ns & 2.843 & ns \\
\hline$W \times C$ & 1.327 & ns & 0.847 & ns & 2.198 & ns & 4.241 & $<0.049$ & 4.026 & ns \\
\hline$S \times W \times C$ & 6.179 & $<0.019$ & 9.268 & $<0.005$ & 5.864 & $<0.022$ & 5.037 & $<0.033$ & 2.006 & ns \\
\hline
\end{tabular}

$n s$, non-significant $(P>0.05)$. $F$ and $P$ values for the repeated measures ANOVA with soil texture, water, $\mathrm{CO}_{2}$ concentration, temperature and their interactions as aboveground growth characteristics as response variables. 

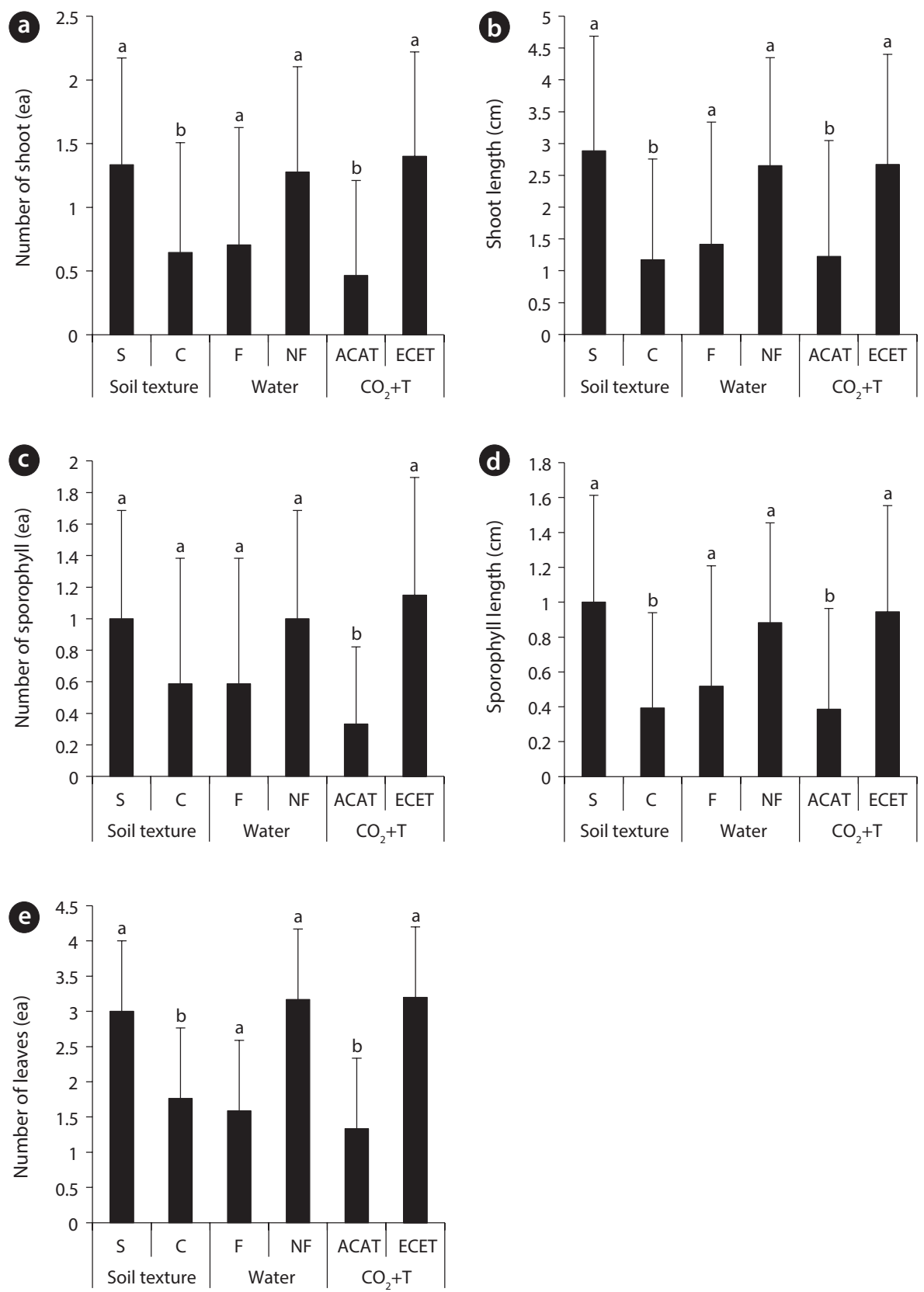

Fig. 1. Number of shoot (a), number of sporophyll (b), number of leaves (c), shoot length (d) and sporophyll length (e) of Mankyua chejuense grown under the soil texture $\left(\mathrm{S}\right.$, sand; $\mathrm{C}$, clay), water regimes ( $\mathrm{F}$, flooding; $\mathrm{NF}$, non-flooding) and $\mathrm{CO}_{2}+\mathrm{T}\left(\mathrm{ACAT}\right.$, ambient $\mathrm{CO}_{2}$ and ambient temperature; $\mathrm{ECET}$, elevated $\mathrm{CO}_{2}$ and elevated temperature) treatments. Different lower cases on the bars indicate significant differences within environmental factors (Fisher's least significant difference, $P<0.05)$.

zome increment in the non-flooding treatment were 3.6and 9.8-fold higher than in the flooding treatment respectively. In the $\mathrm{CO}_{2}$ and temperature treatments, the growth increments in number and total area of rhizome were approximately 2.7- and 4.2-fold higher in the ACAT than in the ECET. However, soil texture effects were not detected in the growth increment of number and total area of rhi- zome.

Mankyua chejuense grown in the sand treatments had significantly greater rhizome length increment than those in the clay treatments, and the mean rhizome length increment amounted to $2.7 \mathrm{~cm}$ in the ACAT but $6.0 \mathrm{~cm}$ in the ECET during two years (Fig. 2b). Rhizome diameter was not significantly affected by soil texture water regimes 

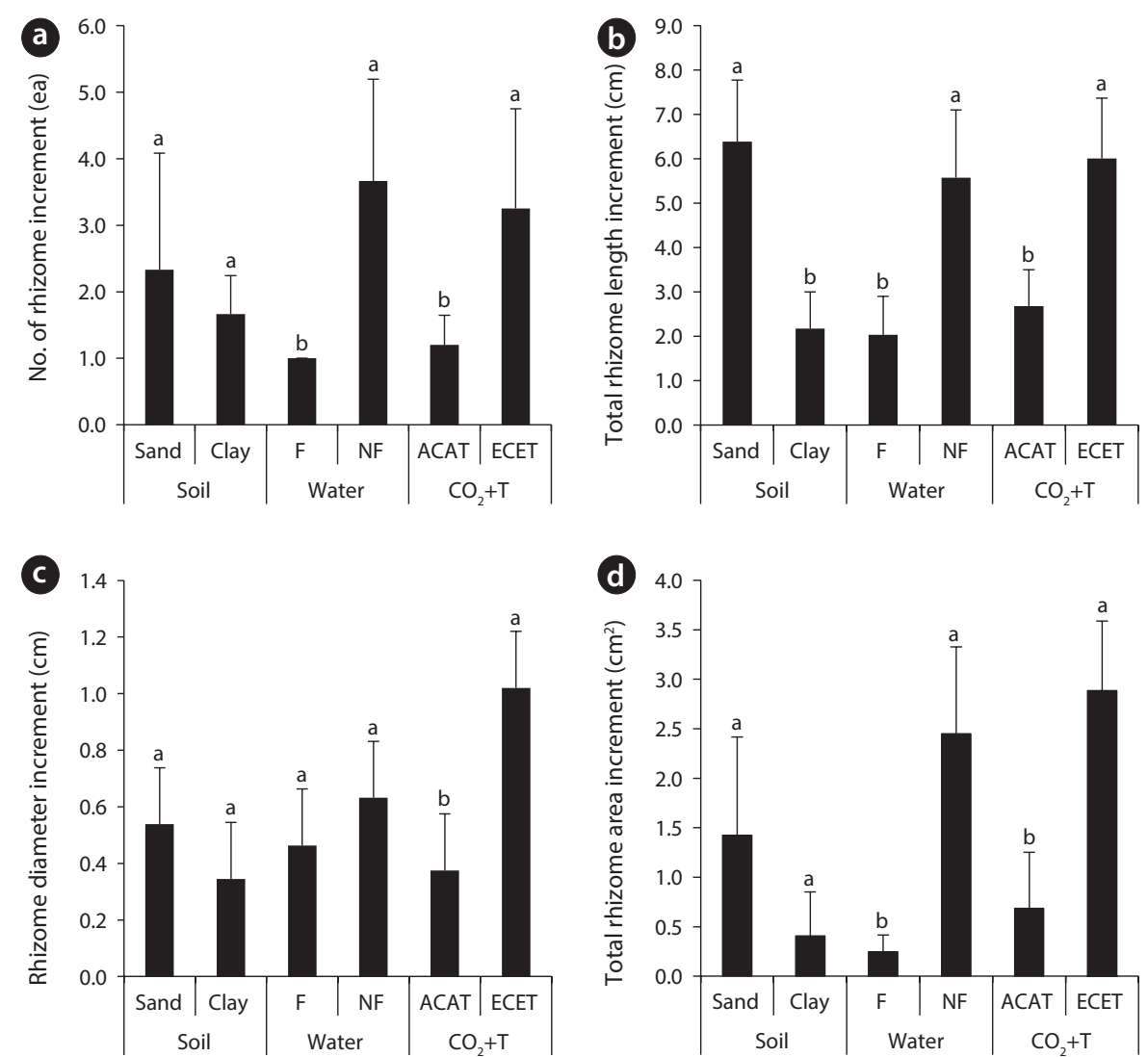

Fig. 2. Variation of mean growth increment in number of rhizome (a), total rhizome length (b), rhizome diameter (c) and total rhizome area (d) of Mankyua chejuense grown under the soil texture $\left(\mathrm{S}\right.$, sand; $\mathrm{C}$, clay), water regimes ( $\mathrm{F}$, flooding; $\mathrm{NF}$, non-flooding) and $\mathrm{CO}_{2}+\mathrm{T}\left(\mathrm{ACAT}\right.$, ambient $\mathrm{CO}_{2}$ and ambient temperature; ECET, elevated $\mathrm{CO}_{2}$ and elevated temperature) treatments from November 2009 to 2011. Different lower cases on the bars indicate significant differences within environmental factors (Fisher's least significant difference, $P<0.05$ ).

while the increment in rhizome diameter of $M$. chejuense grown in the ECET was 4.2-fold higher than those grown in the ACAT (Fig 2).

Elevated $\mathrm{CO}_{2}$ concentration and temperature stimulated rhizome growth for M. chejuense (Fig. 2b). Many researchers determined that carbon allocation on the root could be improved under elevated $\mathrm{CO}_{2}$ and temperature, and then the ratio of belowground to aboveground increased (Rogers et al. 1996). Changes in belowground growth resulting from $\mathrm{CO}_{2}$ enrichment and increased temperature will affect plant function and nutrient absorbability (Pritchard and Rogers 2000). Thus, elevated

Table 2. Effects of environmental factors and their interactions on belowground growth of Mankyua chejuense

\begin{tabular}{|c|c|c|c|c|c|c|c|c|}
\hline \multirow{2}{*}{ Factor } & \multicolumn{2}{|c|}{ No. of rhizome } & \multicolumn{2}{|c|}{ Total rhizome length $(\mathrm{cm})$} & \multicolumn{2}{|c|}{ Rhizome diameter $(\mathrm{cm})$} & \multicolumn{2}{|c|}{ Total rhizome area $\left(\mathrm{cm}^{2}\right)$} \\
\hline & $F$ & $P$ & $F$ & $P$ & $F$ & $P$ & $F$ & $P$ \\
\hline Soil texture $(S)$ & 0.106 & ns & 0.015 & ns & 0.043 & ns & 0.027 & ns \\
\hline Water $(W)$ & 14.734 & $<0.018$ & 5.222 & $<0.044$ & 5.683 & $<0.049$ & 7.169 & $<0.045$ \\
\hline $\mathrm{CO}_{2}+\mathrm{T}(C)$ & 3.086 & ns & 4.079 & $<0.047$ & 8.206 & $<0.046$ & 5.306 & $<0.033$ \\
\hline$S \times W$ & 0.038 & ns & 2.642 & ns & 0.175 & ns & 1.150 & ns \\
\hline$S \times C$ & 0.038 & ns & 0.699 & ns & 0.003 & ns & 0.557 & ns \\
\hline$W \times C$ & 1.528 & ns & 0.156 & ns & 0.013 & ns & 0.477 & ns \\
\hline$S \times W \times C$ & 0.106 & ns & 0.282 & ns & 0.594 & ns & 0.030 & ns \\
\hline
\end{tabular}

$n s$, non-significant $(P>0.05)$. $F$ and $P$ values for the repeated measures ANOVA with soil texture, water, $\mathrm{CO}_{2}$ concentration, temperature and their interactions as belowground growth characteristics as response variables. 


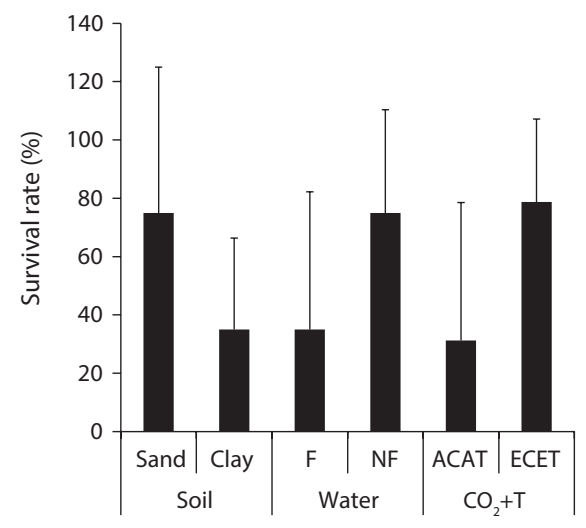

Fig. 3. The survival rate (\%) of Mankyua chejuense in response to three environmental factors (soil texture, water regimes, and $\mathrm{CO}_{2}+\mathrm{T}$ ). $\mathrm{F}$, flooding; $\mathrm{NF}$, non-flooding; ACAT, ambient $\mathrm{CO}_{2}$ and ambient temperature; ECET, elevated $\mathrm{CO}_{2}$ and elevated temperature. Error bars represent standard deviation.

$\mathrm{CO}_{2}$ concentration and temperature may positively affect rhizome growth of $M$. chejuense.

Mankyua chejuense grown at sand, non-flooding and elevated $\mathrm{CO}_{2}+\mathrm{T}$ conditions had a higher rate of survival to the plant grown at sand, flooding and ambient $\mathrm{CO}_{2}+\mathrm{T}$ (Fig. 3).

We found that there was a significant effect of water regimes and elevated $\mathrm{CO}_{2}$ and temperature on the aboveand below-ground growth of M. chejuense (Table 1 and 2). In general, soil moisture is the most significant environmental factor affecting plant growth and population structure. Also, there is a positive relationship between pteridophyte species richness and water availability (Bickford and Laffan 2006). For example, in habitats of M. chejuense, water passes through soil relatively quickly because of high permeable soil originated volcanic rocks, and it is thus usually dry except during the summer rainy season, and Shin (2012) found that abundant habitats with the M. chejuense showed shorter flooding time than in rare one. In this study, we discovered that soil nonflooding conditions negatively affected on growth of $M$. chejuense. Thus, if flooding is prolonged in stages of plant development, the above- and below-ground growth of $M$. chejuense may be negatively affected.

Scenarios for future global and regional climate change will include elevated atmospheric $\mathrm{CO}_{2}$ (Jones 2000), warmer average air temperatures and increasing the frequency of severe weather events, such as flooding (IPCC 2007). Under future climate change, the growth and survival of $M$. chejuense may positively be affected by elevated $\mathrm{CO}_{2}$ and temperature, but not negatively be affected by flooding conditions. Thus, it can be concluded that the optimal growth environmental conditions in habitats of $M$. chejuense is a well-drained and sand soil conditions and increasing $\mathrm{CO}_{2}$ concentration and high temperature will greatly enhance growth of $M$. chejuense as long as drainage maintenance is performed in natural habitat in case of flash floods under future climate change situation.

\section{ACKNOWLEDGMENTS}

This study was supported by the Long-Term Ecological Research Program of the Ministry of the Environment, Republic of Korea.

\section{LITERATURE CITED}

Baruch Z, Jackson RB. 2005. Responses of tropical native and invader $\mathrm{C}_{4}$ grasses to water, stress, clipping and increased atmospheric $\mathrm{CO}_{2}$ concentration. Oecologia 145: 522-532.

Bickford SA, Laffan SW. 2006. Multi-extent analysis of the relationship between pteridophyte species richness and climate. Glob Ecol Biogeogr 15: 588-601.

Chapin FS, Bloom AJ, Field CB, Waring RH. 1987. Plant responses to multiple environmental factors. Bioscience 37: 49-57.

Hyeon HJ, Moon MO, Kim MH. 2011. Vegetation characteristics of Mankyua chejuense habitats. Korean J Plant Res 24: 395-403.

IPCC. 2007. Climate change 2007: Mitigation of climate change. Contribution working group III contribution to the fourth assessment report of the intergovernmental panel on climate change. Cambridge university press, New York.

Jeffries MJ. 2006. Biodiversity and Conservation, 2nd ed. Routledge, London.

Kim CH. 2004. Conservation status of the endemic fern Mankyua chejuense (Ophioglossaceae) on Cheju Island, Republic of Korea. Oryx 38: 217-219.

Kim YS. 2006. Conservation of plant diversity in Korea. Landsc Ecol Eng 2: 163-170.

Kimball BA, Mauney JR, Nakayama FS and Idso SB. 1993. Effects of increasing atmospheric $\mathrm{CO}_{2}$ on vegetation. Vegetatio 104: 65-75.

Jones RN. 2000. Managing uncertainty in climate change projections-issues for impact assessment. Climatic Change 45: 403-419.

Lee KM, Shin JH, Jeong HM, Kim HR, Kim JH, Shin DH, You YH. 2012. Characteristics of vegetation structure and 
habitat of Mankyua chejuense (Ophioglssaceae), endangered plant to Jejudo in Korea. J Wetlands Res 14: 35-45. (in Korean with English abstract)

McMaster RT. 1996. Vegetative Reproduction Observed in Ophioglossum pusillum Raf. American Fern Journal 86 : 58-60.

Ministry of Environment of Korea - UNDP/GEF Korea Wetland Project. 2009. Korean red data book-and invasive species in Korea. Ministry of Environment.

Parmesan C, Yohe G. 2003. A globally coherent fingerprint of climate change impacts across natural systems. Nature 421: 37-42.

Pritchard SG, Rogers HH. 2000. Spatial and temporal deployment of crop roots in $\mathrm{CO}_{2}$-enriched environments. New Phytol 147: 55-71.

Rogers GS, Milham PJ, Thibaud MC, Conroy JP. 1996. Interactions between rising $\mathrm{CO}_{2}$ concentration and nitrogen supply in cotton. I. Growth and leaf nitrogen concentration. Aust J Plant Physiol 23: 119-125.

Sakai AK, Allendorf FW, Holt JS, Lodge DM, Molofsky J, With KA, Baughman S, Cabin RJ, Cohen JE, Ellstrand NC, McCauley DE, O’Neil P, Parker IM, Thompson JN, Weller SG. 2001. The population biology of invasive species.
Annu Rev Ecol Syst 32: 305-332.

Shin JH. 2012. Habitat characteristics and population ecology of Mankyua chejuense (Ophioglossaceae) and its ecological response to environment treatment. MS Thesis. Kongju National University, Gongju, Korea.

Smith M, Wu Y, Green O. 1993. Effect of light and waterstress on photosynthesis and biomass production in Boltonia decurrens (Asteraceae), a threatened species. Am J Bot 80: 859-864.

Song L, Wu J, Li C, Li F, Peng S, Chen B. 2009. Different responses of invasive and native species to elevated $\mathrm{CO}_{2}$ concentration. Acta Oecol 35: 128-135.

Sun BY, Kim MH, Kim CH, Park CW. 2001. Mankyua (Ophioglossaceae): a new fern genus from Cheju Island, Korea. Taxon 50: 1019-1024.

Yatskievych G. 2003. Pteridophytes (Ferns). Encyclopedia of Life Science. DOI: 10.1038/ npg.els.0003679.

You YH, Kim HR. 2010. Key factors causing the Euryale ferox endangered hydrophyte in Korea and management strategies for conservation. J Wetlands Res 12: 49-56. (in Korean with English abstract)

Zar JH. 2009. Biostatistical Analysis. 5th ed. Prentice-Hall, Upper Saddle River, NJ. 